Military Technical College

Kobry Elkobbah,

Cairo, Egypt

May $29-31,2012$

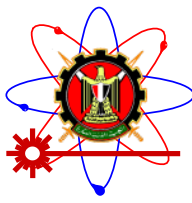

$6^{\text {th }}$ International Conference

on Mathematics and

Engineering Physics

(ICMEP-6)

\title{
The Effect of Laser Wavelength on The Microstructure Features of SS316L During Laser Irradiation
}

\author{
Hebatalrahman, $\mathrm{A}^{(1)}$ \\ Dr.eng .Consultant in materials sciences \& materials applications, Egypt ${ }^{(1)}$ \\ hebatalrahman11@yahoo.com \\ hebatalrahman@naseej.com
}

\begin{abstract}
s
In these work, New technique for harden stainless steel 316L and similar alloys which does not harden in response to heat treatments will be developed by laser irradiation .The goal of this study is to investigate the effect of laser wavelengths at the same repetion rate, energy per pulse and number of pluses on different hardening routes for 316L stainless steel by laser surface irradiation. For each hardening route we present the microstructure, modulus and the Hardness of the processed surface and the conditions leading to the best compromise between. highest hardness, reasonable modulus and best homogeneity in microstructure features The results show that the laser treatment improves the properties of AISI 316L stainless steel. This improvement is not associated with distinctive changes in mechanical properties, rather it is attributed to microstructure. In fact the process is complicated and limited to certain laser irradiation conditions depends mainly on the original microstructure.
\end{abstract}

Key words laser, irradiation, nano-indentation, qualitative, qualitative analysis, stainless steel

\section{Introduction}

Grade 316 is the standard molybdenum-bearing grade, second in importance to 304 amongst the austenitic stainless steels. The molybdenum gives 316 better overall corrosion resistant properties than Grade 304, particularly higher resistance to pitting and crevice corrosion in chloride environments ${ }^{(1),(2)}$. Grade 316L, the low carbon version of 316 and is immune from sensitisation (grain boundary carbide precipitation). Thus it is extensively used in heavy gauge welded components (over about $6 \mathrm{~mm}$ ). There is commonly no appreciable price difference between 316 and 316L stainless steel. The austenitic structure also gives these grades excellent toughness, even down to cryogenic temperatures (3),(4). Compared to chromium-nickel austenitic stainless steels, 316L stainless steel offers higher creep, stress to rupture and tensile strength at elevated temperatures. These properties are specified for flat rolled product (plate, sheet and coil) in ASTM A240/A240M. Similar but not necessarily identical properties are specified for other products such as pipe and bar in their respective specifications ${ }^{(5)}$ : (7).

Corrosion Resistance is Excellent in a range of atmospheric environments and many corrosive media generally more resistant than 304. Subject to pitting and crevice corrosion in warm chloride environments, and subject to stress corrosion cracking above about $60^{\circ} \mathrm{C}$. Considered resistant to potable water with up to about $1000 \mathrm{mg} / \mathrm{L}$ chlorides at ambient temperatures, reducing to about $500 \mathrm{mg} / \mathrm{L}$ at $60^{\circ} \mathrm{C}^{(8),(9)}$.

316 is usually regarded as the standard "marine grade stainless steel", but it is not resistant to warm sea water. In many marine environments 316 does exhibit surface corrosion, usually visible as brown staining. This is particularly associated with crevices and rough surface finish ${ }^{(10),(11)}$.

Heat Resistance is Good oxidation resistance in intermittent service to $870^{\circ} \mathrm{C}$ and in continuous service to $925^{\circ} \mathrm{C}$. Continuous use of 316 in the $425-860^{\circ} \mathrm{C}$ range is not recommended if subsequent aqueous corrosion resistance is important ${ }^{(12),(13)}$.

Grade $316 \mathrm{~L}$ is more resistant to carbide precipitation and can be used in the above temperature range

${ }^{(14)}$. Grade $316 \mathrm{H}$ has higher strength at elevated temperatures and is sometimes used for structural and pressure-containing applications at temperatures above about $500^{\circ} \mathrm{C}^{(15),(16)}$.

Heat Treatment is Solution Treatment (Annealing) - Heat to $1010-1120^{\circ} \mathrm{C}$ and cool rapidly. These grades cannot be hardened by thermal treatment ${ }^{(17)}$. 
Military Technical College

Kobry Elkobbah, Cairo, Egypt

May 29-31,2012

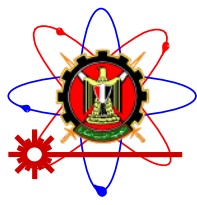

$6^{\text {th }}$ International Conference

on Mathematics and

Engineering Physics

(ICMEP-6)

Welding Excellent weldability by all standard fusion and resistance methods, both with and without filler metals. Heavy welded sections in Grade 316 require post-weld annealing for maximum corrosion resistance. This is not required for $316 \mathrm{~L}$. $316 \mathrm{~L}$ stainless steel is not generally weldable using oxyacetylene welding methods ${ }^{(18),(19)}$

Machining of $316 \mathrm{~L}$ stainless steel tends to work harden if machined too quickly. For this reason low speeds and constant feed rates are recommended. 316L stainless steel is also easier to machine compared to 316 stainless steel due its lower carbon content ${ }^{(20),(21)}$.

Hot and Cold Working of 316L stainless steel can be hot worked using most common hot working techniques. Optimal hot working temperatures should be in the range $1150-1260^{\circ} \mathrm{C}$, and certainly should not be less than $930^{\circ} \mathrm{C}$. Post work annealing should be carried out to induce maximum corrosion resistance. Most common cold working operations such as shearing, drawing and stamping can be performed on 316L stainless steel. Post work annealing should be carried out to remove internal stresses (22),(23)

Hardening and Work Hardening of $316 \mathrm{~L}$ stainless steel does not harden in response to heat treatments. It can be hardened by cold working, which can also result in increased strength ${ }^{(25),(26)}$.

\section{Experimental Work \\ Material}

The alloys used throughout this work was supplied by Sandvik Co, France in the form of rods of $8 \mathrm{~mm}$ diameter, Table (1) lists the alloy type and their main applications, while chemical compositions of ferrous alloy are listed in Tables (2).

Table (1) Alloy Used in the Experimental Work ${ }^{(27):(29)}$

\begin{tabular}{|l|l|l|}
\hline Alloy & Fonm & Mam application \\
\hline Stainless & Rod $\Phi(8 \mathrm{~mm})$ & $\begin{array}{l}\text { Slides-N } \mathrm{N} \text { s- fix ation systems, } \\
\text { architecture applications, } \\
\text { implants- otthopedic }\end{array}$ \\
\hline
\end{tabular}

Table (2) chemical compositions of stainless steel 316 ${ }^{(30)}$

\begin{tabular}{|l|l|l|l|l|l|l|l|l|}
\hline Material & $\mathrm{C} \%$ & $\mathrm{~S} \Psi \%$ & $\mathrm{Mn} \%$ & $\mathrm{P} \%$ & $\mathrm{~S} \%$ & $\mathrm{Cr} \%$ & $\mathrm{M} \%$ & $\mathrm{~N} \%$ \\
\hline Austenitic & 0.07 & 1.0 & 2.0 & 0.045 & 0.03 & $16.5:$ & 4.0 & $10.5:$ \\
Stainless steel & & $\max$ & $\max$ & $\max$ & $\max$ & 18.5 & $\min$ & 13.5 \\
316L & & & & & & & & \\
\hline
\end{tabular}

\section{Laser Surface Irradiation}

The surface irradiation of the alloys was studied. Samples used in this investigation were in the standard size for every test according to ASTM. All the experiments were performed at room temperature in air at atmospheric pressure; it was shown elsewhere ${ }^{(10)}$ that the presence of air has no measurable influence on the process of irradiation by UV laser ${ }^{(111)}$. The irradiation is done on one side of the sample and covers all the surface area of the sample. The main goal of this work is optimize condition for laser irradiation of the samples by Excimer laser at 308nm Table (3) shows data for used rare gas halide Excimer laser. 
Military Technical College

Kobry Elkobbah,

Cairo, Egypt

May 29-31,2012

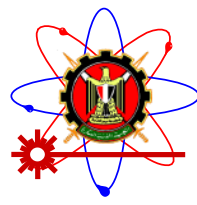

$6^{\text {th }}$ International Conference

on Mathematics and

Engineering Physics

(ICMEP-6)

Table (3) Data for Excimer Laser (rare gas halide) .

\begin{tabular}{|l|l|l|l|l|l|}
\hline $\begin{array}{l}\text { Gas } \\
\text { type }\end{array}$ & $h$ (num) & $\mathbf{r ( A )}$ & $\omega\left(\mathbf{C m}^{-1}\right)$ & $\sigma\left(\mathbf{C m}^{2}\right)$ & $\tau$ (ns) \\
\hline $\mathrm{ArF}$ & 193 & 2.2 & - & 12 & 4.2 \\
$\mathrm{XeC1}$ & 308 & 2.9 & 194 & 50 & 11 \\
\hline
\end{tabular}

$\lambda=$ transition wavelength

r(A) = equilibrium inter-nuclear separation

$\boldsymbol{\omega}=$ fundamental vibration frequency of the excited state

$\boldsymbol{\sigma}=$ stimulated emission cross section

$\tau=$ radiative life time (pulse duration)

The number of pulses and the effect of energy per pulse on the hardness were recorded to indicate the energy required (fluence) to improve the mechanical properties. In the shape of a rectangle with width $(\mathrm{w}=4 \mathrm{~mm})$ and length $(1=10 \mathrm{~mm})$ was used in the laser process the power density ranges from $(0.75$ $\mathrm{W} / \mathrm{Cm}^{2}$ to $0.1 \mathrm{~W} / \mathrm{Cm}^{2}$ ) without any focusing. The laser irradiation condition is listed in Table (3)

Table (3) Laser Irradiation Conditions

\begin{tabular}{|c|c|c|c|c|}
\hline Type & $\begin{array}{l}\text { Wavelength } \\
\mathrm{nm}\end{array}$ & No of pulses & $\begin{array}{l}\text { Energy per } \\
\text { pulse } \\
\text { mJ }\end{array}$ & $\begin{array}{l}\text { Repetition } \\
\text { rate (H) }\end{array}$ \\
\hline Exrimer & UV 3086 & $\begin{array}{l}0,200,500,10020 \\
15000,5000\end{array}$ & 6 & 200 \\
\hline Exrimer & UV 193 & $\begin{array}{l}0,200,500,10200 \\
15000,5000\end{array}$ & 6 & 200 \\
\hline
\end{tabular}

\section{Mechanical tests}

Nanoindentation was used to determine film hardness and elastic modulus using a Nanotest 600 instrument from Micro materials Ltd with a Berkovich (three-sided pyramidal) diamond indenter. The peak loads in the rage $1-200 \mathrm{mN}$ were used, with loading rate $=$ unloading rate that were varied in proportion to the peak loads starting at a value of $0.05 \mathrm{mN} / \mathrm{s}$ for the 1 indentations, while common experimental conditions as initial (contact) load $0.05 \mathrm{mN}$ and holding period at peak load $10 \mathrm{~s}$ were used for all the measurements. The indentations were repeated at least five times at each load on different regions of the sample surface apart $100 \mathrm{~m}$. The hardness and reduced modulus have been determined from these indentation curves using a method originally proposed by Oliver and Pharr, which fits a power-law function to the unloading curve.

\section{Metallographic Examinations}

The specimens were prepared for examination first by grinding on different grades of silicon carbide "SiC" papers coarse grinding followed by fine grinding at 180,240,320,400,600, and 800 finally polishing was conducted with Alumina powder $(3 \mu \mathrm{m})$ size. The details of the microstructure were revealed after etching by standard etching solution of the alloy selected. All specimens had to be etched and polish several times to obtain best results and to produce a uniform level of sample examination. Table (4) shows the etching solutions used for the investigated alloys. 
Military Technical College

Kobry Elkobbah,

Cairo, Egypt

May 29-31,2012

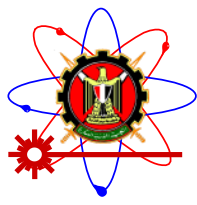

$6^{\text {th }}$ International Conference

on Mathematics and

Engineering Physics

(ICMEP-6)

The surfaces of the samples before and after laser irradiation were examined using Olympus optical microscope Model BHM at selected magnification

Table (4) shows the etching solutions used for stainless steel 316L

\begin{tabular}{|l|l|l|l|}
\hline Alloy & Etchant & condiiions & Remarks \\
\hline SS316L & Hydrochloric acid(40\%) & $45 \mathrm{ml}$ & Immergd \\
& Nitric acid (1.40) & $15 \mathrm{ml}$ & $5-15 \mathrm{sec}$ \\
& methanol & $20 \mathrm{ml}$ & \\
\hline
\end{tabular}

\section{Quantitative Metallography Measurements}

A quantitative analysis of the microstructures was produced carried out over 4 fields across the surface to indicate:

1. Average grain size number by linear intercept technique.

2. Average grain diameters $\mathrm{D}_{\mathrm{A}}$ using number of modules per unit area

3. Average intercept distance $\mu \mathrm{m}$

4. Area of average grain section $\mathrm{mm}^{2} \times 10^{\wedge^{6}}$

5. Average number of grains per $\mathrm{mm}^{3} \times 10^{\wedge}$

6. Nominal grains per $\mathrm{mm}^{2}$

7. Nominal grains per $\mathrm{mm}^{2}$ at $100 \mathrm{x}$

calculations were carried out in several areas in each specimen investigated at $100 \mathrm{X}$ projected on a screen measuring $500 \mathrm{~mm}^{2}$. The measurement is average of over five readings at least for each condition. The scattering value for each specimen was $\pm 1 \%$. All calculations were measured around a circle to consider all directions $360^{\circ}$

\section{Results \& discussions}

The variation in mechanical properties due to laser irradiation at different wavelengths were measured. Figure (1) and figure (2) show the variation of modulus and hardness at maximum load with number of pulses,

Fig (1) shows the variation of Modulus at maximum load with number of pulses, the value of modulus increased until 5000 pulses. The decreasing rate in modulus after 5000 pulses was very slow. The variation of hardness at maximum load with number of pulses at $308 \mathrm{~nm}$ and $193 \mathrm{~nm}$ Excimer laser irradiation was shown in Fig (2). The hardness value at 2000 pulses is increase slightly. Improvement in the hardness was significant only at 5000pulses, between 10250 pulses and 15000 pulses the hardness is improved relative to the base material but they are less than maximum value at 5000 pulses. When the number of pulses increased the hardness value decreased due to sample burning. the value of modulus increased until 5000pulses. The decreasing rate in hardness and modulus after 15000 pulses was very slow.

The effect of the number of laser pulses on the hardness and modulus when stainless steel 316L was irradiated at $193 \mathrm{~nm}$ and $308 \mathrm{~nm}$ has similar behavior. The beam energy at $193 \mathrm{~nm}$ pulses is larger than the beam energy at $308 \mathrm{~nm}$. According to the energy equations and principles were low wavelengths means higher frequency and higher amount of energy absorbed. The improvement at $308 \mathrm{~nm}$ is better in some points due to grain gross which will be explained in terms of microstructure. The initial microstructure of the irradiated alloy (the room temperature microstructure) plays the significant role in that case. The decrease in hardness of stainless steel after laser irradiation is due to the formation of higher energy phases but these phases have lower hardness. 
Military Technical College

Kobry Elkobbah,

Cairo, Egypt

May 29-31,2012

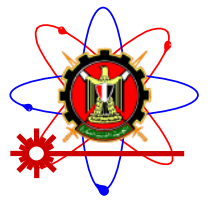

$6^{\text {th }}$ International Conference on Mathematics and Engineering Physics (ICMEP-6)
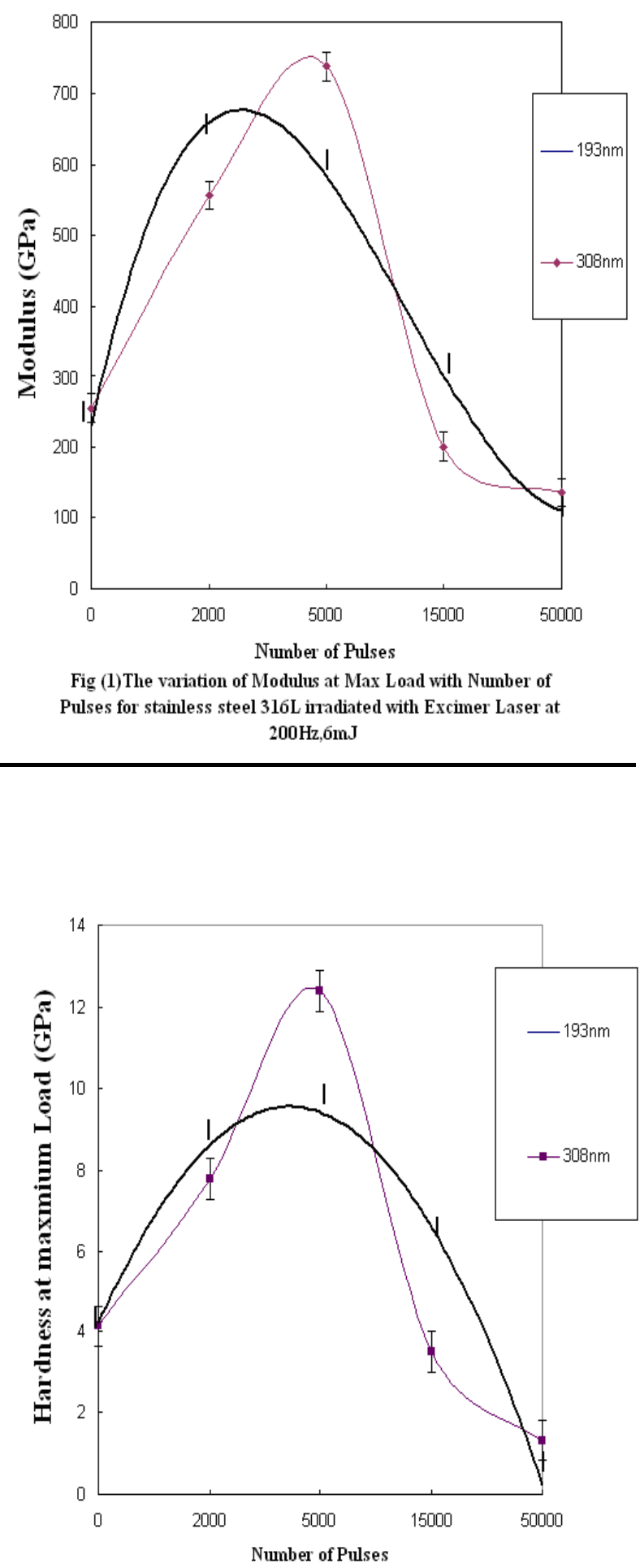

Fig(2) The variation of Hardness at Max Load with Number of Pulses for stainless steel 316L irradiated with Excimer Laser at $200 \mathrm{~Hz}, 6 \mathrm{~mJ}$

\section{Qualitative analysis of stainless steel 316L}

The microstructure of untreated austenitic stainless steel 316L contains Austenite, ferrite and Carbides. Figure (3)-a shows the microstructure of the untreated sample 


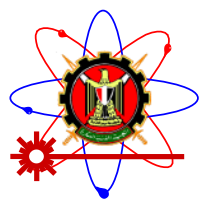

Figure (3)-b,c and Figure (4)-a,b show the microstructure of the sample treated at 5000 pulses and 15000 pulses when the laser wavelength was $193 \mathrm{~nm}$ and $308 \mathrm{~nm}$ respectively, there is small portion of ferrite and carbides transformed to martensite.

The laser irradiation gives the samples the energy required for phase transition. Phase transition process leads to austenization of the ferrite. The austenite matrix become rich in carbon because of the diffusion process of carbon from carbides. On rapid cooling, the carbon enriched austenite transforms into martensite and austenite appear in the microstructure because of high percentage of (Ni) and other $\gamma$ stabilizers.

Martensite is produced by rapid self quenching of austenite due to heat transfer from laser heated layer to the bulk material. The high thermal conductivity of the stainless steel increases the cooling rate and plays a significant role in the phase transformation process. Mechanism and results explained above agree with published results deals with ductile cast iron ${ }^{(11):(15)}$.

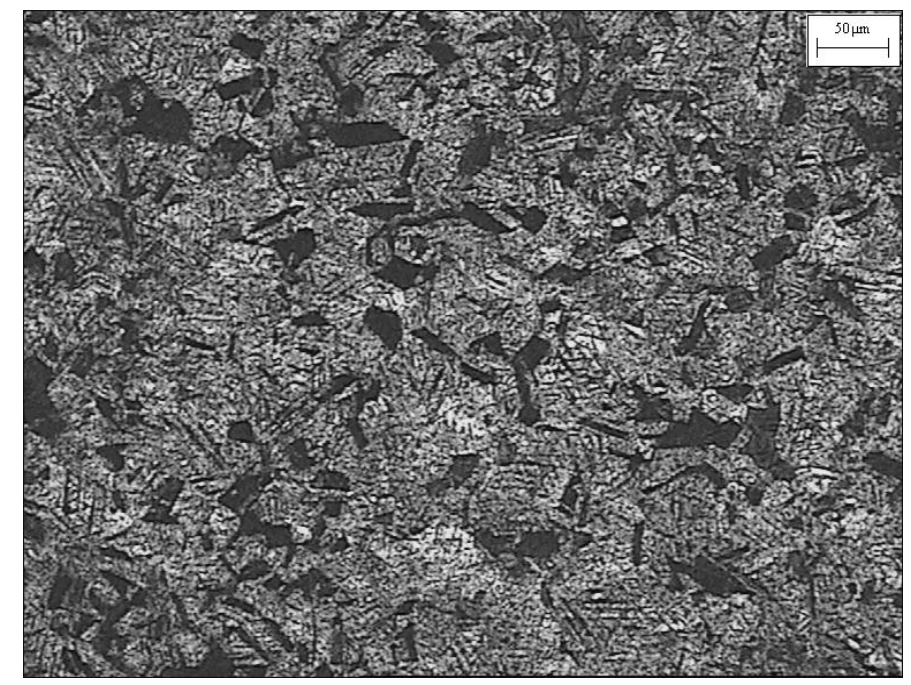

(a) untreated

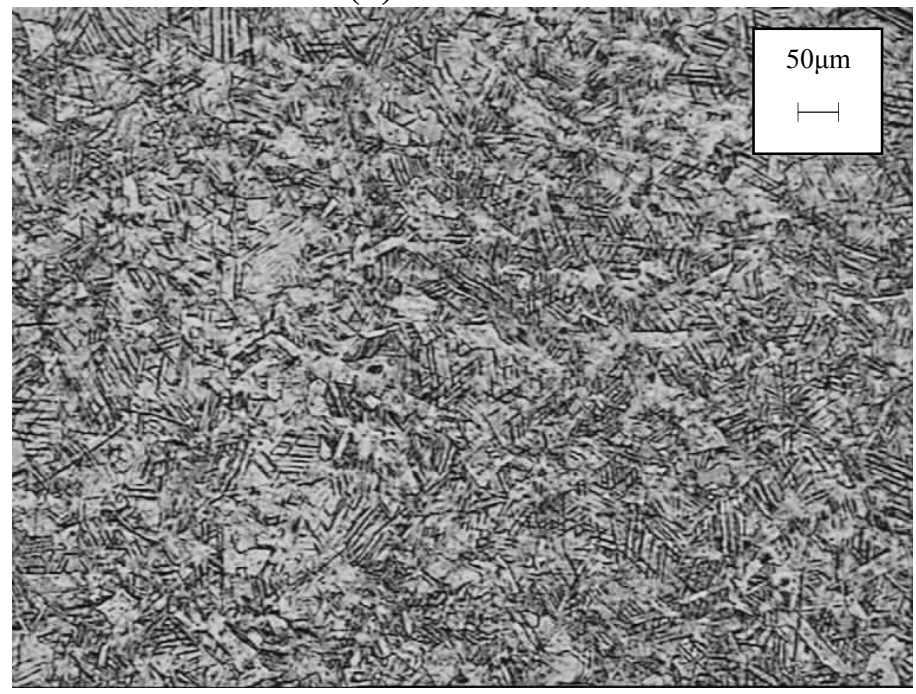

(b)5000pulses 
Military Technical College Kobry Elkobbah, Cairo, Egypt May 29-31,2012

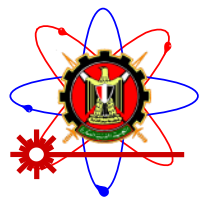

$6^{\text {th }}$ International Conference on Mathematics and Engineering Physics (ICMEP-6)

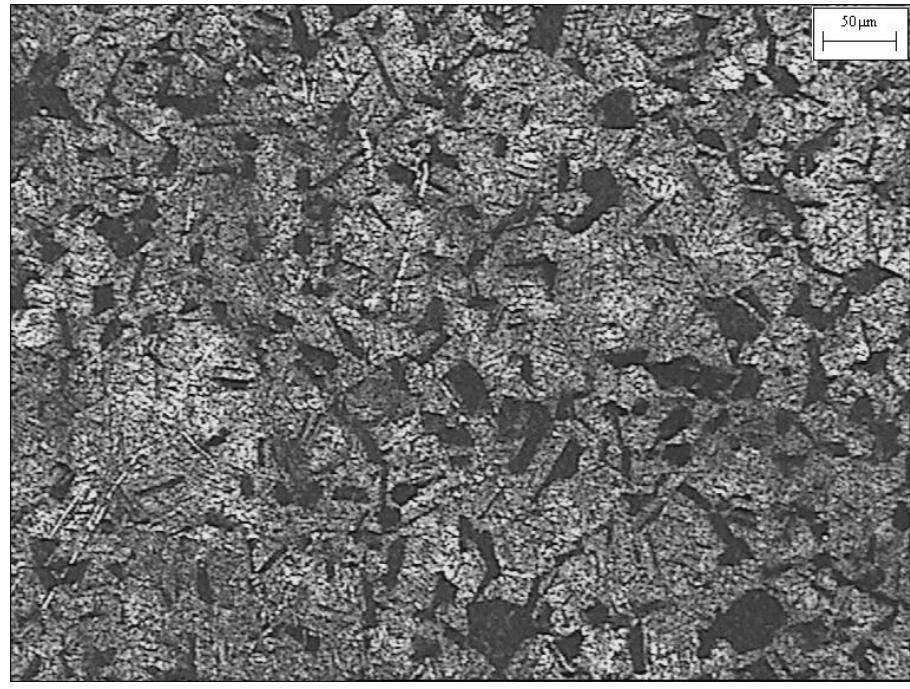

(c)15000pulses

Fig(3) Excimer Laser Irradiated of Stainless Steel 316L at 308nm, 6mJ, 200Hz, 100x at different number of pulses

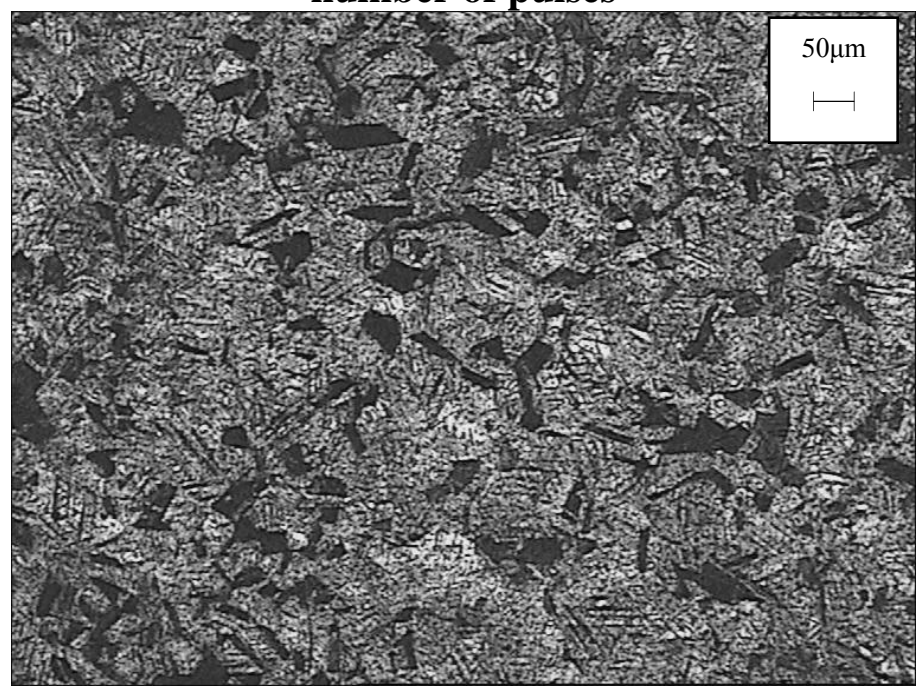

(a)5000pulses

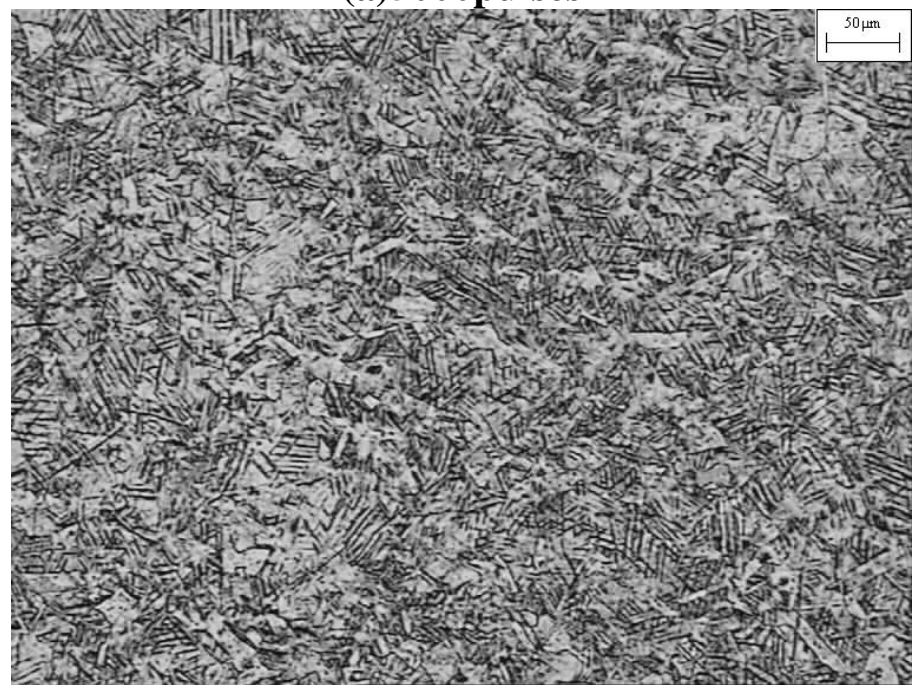

(b)15000pulses

Fig(4) Excimer Laser Irradiated of Stainless Steel 316L at 193nm, 6mJ, 200Hz, 100x at different number of pulses 
Military Technical College

Kobry Elkobbah,

Cairo, Egypt

May 29-31,2012

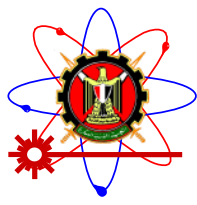

$6^{\text {th }}$ International Conference

on Mathematics and

Engineering Physics

(ICMEP-6)

The microstructure results disagree with the published results use relatively high power of laser beam. In the present work, there is no melting observed, while in the previous work mentioned above there are three different zones: melting zone, transition zone, and transformed zone generated by the heating effect of the high power ${ }^{(31),(32)}$.

The microstructure analysis in other published data ${ }^{(11)}$ is presented to predict microstructure due to laser melting and rapid solidification of AISI 304 during welding at laser power 380W. The solidification rate produces the cellular microstructure. The formation of various types of microstructure depends on the solidification rate. The dendritic, planar and cellular solidification structures can be predicted corresponding to laser processing. The difference between current results.

Published literature ${ }^{(78)}$ prove that with the increase of laser power and the scanning rate, the depth of the hardened zone decreases. During the processing, the laser heats up the workpiece surface, then the temperature of which is elevated above Ac1-the temperature of austenizing. After laser beam is moved away, workpiece self-quenches at a very high cooling speed and martensites are produced in it. Carbon atoms will diffuse to the austenite adequately, and then material can be successfully hardened. The results recorded by the literature is relatively agree with current results due to the difference in laser power and mechanism of surface treatment ${ }^{(33)}$.

\section{Quantitative analysis}

The quantitative metallography produces a significant change in grain sizes for stainless steel 316L which leads to changes in microstructure features and distribution of grains per unit area as shown in table (6)

Table (6) Average grain size for stainless steel 316L irradiated by Excimer Laser 308nm,200Hz,6mJ

\begin{tabular}{|c|c|c|c|c|c|c|}
\hline \multirow{2}{*}{$\begin{array}{l}\text { Mirı-grain } \\
\text { sive } \\
\text { measunements }\end{array}$} & \multirow{2}{*}{\begin{tabular}{|l|} 
Before \\
irradintion
\end{tabular}} & \multicolumn{5}{|c|}{ After inadiation } \\
\hline & & $\begin{array}{l}2000 \\
\text { putses }\end{array}$ & \begin{tabular}{|l|}
10250 \\
pukes
\end{tabular} & \begin{tabular}{|l|}
5000 \\
pulses
\end{tabular} & $\begin{array}{l}15000 \\
\text { pulses }\end{array}$ & $\begin{array}{l}50000 \\
\text { pulses }\end{array}$ \\
\hline $\begin{array}{l}\text { ASTM grain } \\
\text { sive nuuber }\end{array}$ & 9 & 9.5 & 9.5 & 10 & 9.2 & \\
\hline $\begin{array}{l}\text { Dianeter of } \\
\text { average gain } \\
\mu \mathrm{m}\end{array}$ & 16 & 13 & 13 & 11 & 15 & \\
\hline $\begin{array}{l}\text { Average } \\
\text { intercept } \\
\text { distance pun } \\
\end{array}$ & 14.1 & 11.9 & 11.9 & 10 & 13.3 & \\
\hline \begin{tabular}{|l} 
Area of \\
average grain \\
section mint $^{2}$ \\
x $10 \times 6$
\end{tabular} & 225 & 178 & 178 & $120-$ & 225 & 묭 \\
\hline \begin{tabular}{|l} 
Average \\
number of \\
gains per \\
mon $^{3} \times 10^{\wedge} 6$ \\
\end{tabular} & 0.2 & 0.336 & 0336 & 0.566 & 0.237 & 总 \\
\hline $\begin{array}{l}\text { Nominal } \\
\text { gnin } \\
\text { per mant }\end{array}$ & 4440 & 5610 & 5610 & 7940 & 4440 & \\
\hline $\begin{array}{l}\text { Nominal } \\
\text { gainper } \\
\text { mant }^{2} \\
\text { at } 100 x\end{array}$ & $256-287$ & 362 & 362 & $\begin{array}{l}512- \\
645\end{array}$ & 2867 & \\
\hline
\end{tabular}



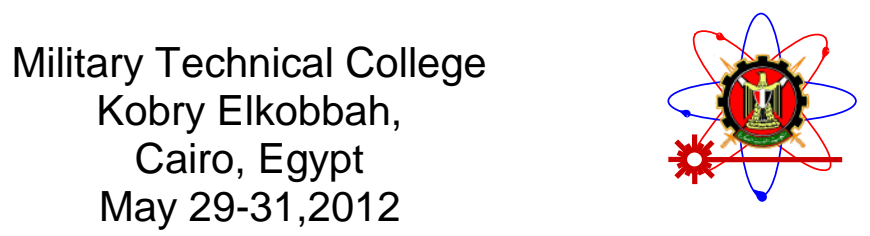
$6^{\text {th }}$ International Conference on Mathematics and Engineering Physics (ICMEP-6)

From the above table the following features may be recorded an increase in the grain size number from 9 to 10 cause a decrease in the size of the grain resulting from the decrease in the grain diameter. In other words the number of grains in the unit area increase from 4440 to 7950 grain per unit area. The refinement occur in the structure was the main reason of improvement in hardness besides the formation of harder phases. Fig (5) shows the variation of grain size number with variation of number of pulses the behaviour is agree with the variation in average diameter of the grains which is recorded in fig (6) as a function of the number of pulses. When comparing the grain size variation with the variation in both hardness and modulus in Fig (1) and Fig (2) respectively, the materials have the same trends measured before. The improvement in mechanical properties due to laser irradiation technique are related to changes in microstructure features during absorption of laser photons of energy. Table (7) shows average grain size for stainless steel 316L irradiated by Excimer Laser 193nm,200Hz,6mJ
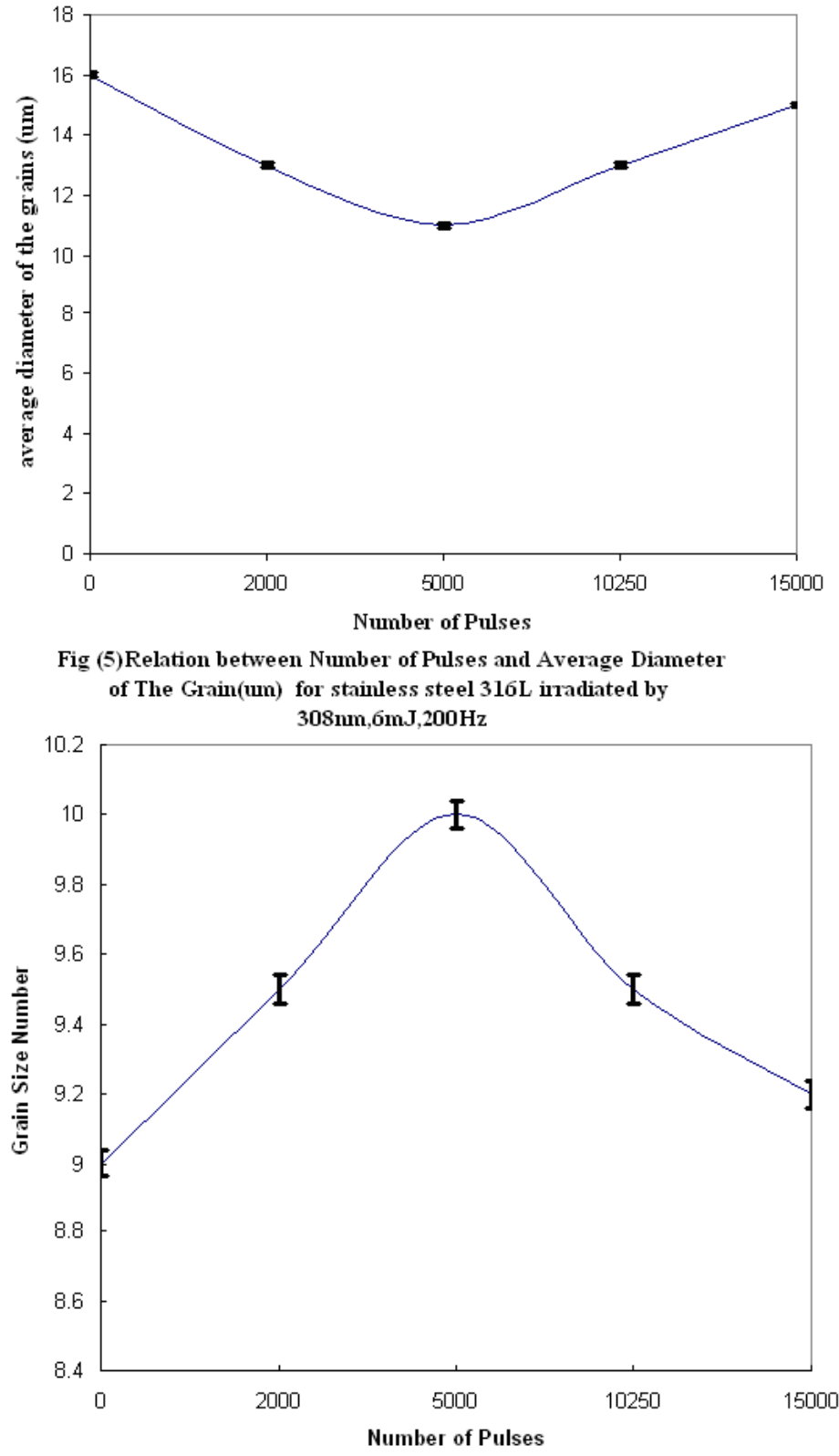

Fig (6)The relation between Number of Pulses and Grain size Number for $316 \mathrm{~L}$ irradiated by $308 \mathrm{~nm}, 6 \mathrm{~mJ}, 200 \mathrm{~Hz}$ 
Military Technical College

Kobry Elkobbah,

Cairo, Egypt

May $29-31,2012$

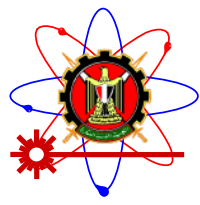

$6^{\text {th }}$ International Conference

on Mathematics and

Engineering Physics

(ICMEP-6)

Table (7) Average grain size for stainless steel 316L irradiated by Excimer Laser $193 \mathrm{~nm}, 200 \mathrm{~Hz}, 6 \mathrm{~mJ}$

\begin{tabular}{|c|c|c|c|c|c|c|}
\hline & Before & & & a inadi & ation & \\
\hline $\begin{array}{l}\text { size } \\
\text { measurements }\end{array}$ & irradiation & $\begin{array}{l}2000 \\
\text { pulses }\end{array}$ & $\begin{array}{l}10250 \\
\text { pulses }\end{array}$ & $\begin{array}{l}5000 \\
\text { pulses }\end{array}$ & $\begin{array}{l}15000 \\
\text { pulses }\end{array}$ & $\begin{array}{l}50000 \\
\text { puses }\end{array}$ \\
\hline $\begin{array}{l}\text { ASTM gain } \\
\text { size number } \\
\text { aterage } \\
\text { Dinmeter of } \\
\text { the gails pan }\end{array}$ & 16 & 16 & $\begin{array}{l}8.5 \\
19\end{array}$ & 16 & 16 & \\
\hline $\begin{array}{l}\text { Average } \\
\text { intercept } \\
\text { distance } \mu \mathrm{m}\end{array}$ & 14.1 & 14.1 & 21 & 14.1 & 14.1 & \\
\hline $\begin{array}{l}\text { Area of average } \\
\text { gain section } \\
\operatorname{mon}^{2} \times 10^{\circ} 6\end{array}$ & 225 & 225 & 365 & 225 & 225 & \\
\hline $\begin{array}{l}\text { Average } \\
\text { number of } \\
\text { gnairs per } \mathrm{mm}^{3} \\
\text { xl0 } 06\end{array}$ & 0.2 & 0.2 & 0.119 & 0.2 & 0.2 & \\
\hline $\begin{array}{l}\text { Nominalgrains } \\
\text { per mut? }\end{array}$ & 4440 & 4440 & 2810 & 4440 & 4440 & \\
\hline
\end{tabular}

The new technique is suitable for for hardening of the alloys does not harden by conventional heat treatment

\section{Conclusions}

1. 316L austenitic stainless steel can be hardened by laser surface irradiation by UV lasers at different number of pulses

2. The phenomena of hardening of materials by lasers can be explained in terms of the changes in micro structure features due to absorption of laser energy which affect grain size and grain distribution.

3. wavelengths have a significant effect on the laser irradiation techniques

4. The process is complicated and limited to certain laser irradiation conditions depends mainly on the original microstructure.

5. The mechanical properties such as hardness and modulus were improved due to laser irradiation. 
Military Technical College

Kobry Elkobbah,

Cairo, Egypt

May 29-31,2012

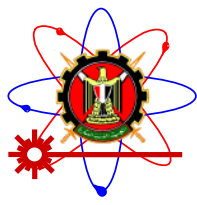

$6^{\text {th }}$ International Conference

on Mathematics and

Engineering Physics

(ICMEP-6)

\section{References}

1. C. Dutouquet, S. Acquaviva, J. Hermann, Detection of boron nitride radicals by emission spectroscopy in a laser-induced plasma, Spectrochimical Acta B: Atomic Spectroscopy 56B 6, (2001), 629-635

2. J. Hermann, F. Coursimault, O. Motret, S. Acquaviva, A. Perrone: Investigation of silicon oxide emission spectra observed in a pulsed discharge and a laser-induced plasma, J. Phys. B: At. Mol. Opt. Phys. 34 (2001), 1917-1927

3. M. De Sario, G. Leggieri, A. Luches, M. Martino, F. Prudenzano, A. Rizzo: Pulsed Laser Deposition Of Praseodymium-Doped Chalcogenide Thin Films, Appl. Surf. Scie. 186 (2002) 216-220.

4. P. Mengucci, G. Barucca, G. Majni, A. Di Cristoforo, G. Leggieri, M. Martino: Coherent carbon nitride phases grown on Si substrates by reactive laser ablation, Recent Res. Devel. Applied Phys. 5 (2002) 69-87

5. A. D’Orazio, M. De Sario, L. Mescia, V. Petruzzelli, F. Prudenzano, A. P. Caricato, G. Leggieri, M. Martino: Design and Fabrication of Praseodymium Doped Optical Waveguides, Proc. SPIE 4645 (2002) 174-182

6. A. P. Caricato, M. Fernandez, G. Leggieri, A. Luches, M. Martino F. Prudenzano: Pulsed laser Deposition of Films and Multilayers for Optoelectronic Applications Proc SPIE 4762 (2002) 41-51

7. S. Acquaviva and M.L. De Giorgi: Temporal and spatial analysis of plasmas during graphite laser ablation, Appl. Surf. Sci. 197-198 (2002) 21-26

8. S. Acquaviva and M.L. De Giorgi: Stoichiometric analyses of $\mathrm{Cd}_{1-\mathrm{x}} \mathrm{Mn}_{\mathrm{x}} \mathrm{Te}$ thin films deposited by pulsed laser ablation, Appl. Surf. Sci. (in press)

9. S. Acquaviva, A.P. Caricato, E. D’Anna, M. Fernández, A. Luches, Z. Frait, E. Majkova, S. Luby, P. Mengucci: Pulsed laser deposition of Co- and Fe-based amorphous magnetic films and multilayers, Thin Solid Films (submitted)

10. Metals handbook (ASM information), $2^{\text {nd }}$ edition, The Material Information Society, 2000.

11. "Deposition of ITO and AZO thin films by laser ablation at $355 \mathrm{~nm}$ in a background atmosphere", Ph.D. Thesis, Birgitte Thestrup, Riso National Laboratory, Roskilde, University of Copenhagen, Denmark, ISBN 97-550-2609-5, ISSN 0106-2840, Feb. 2000.

12. S. Acquaviva, A. Perrone, A. Zocco, A. Klini, C. Fotakis: Deposition of carbon nitride films by reactive sub-picoseconds pulsed laser ablation, Thin Solid Films, 373/1-2 (2000), 266-272

13. S. Acquaviva, E. D’Anna, M. Fernández, G. Leggieri, A. Luches, M. Martino, A. Perrone: Pulsed laser ablation deposition of thin films on large and three-dimensional substrates, Vuoto XXIX, N. 1-2 (2000), 63-64

14. S. Acquaviva, M.L. De Giorgi, M. Fernández, G. Leggieri, A. Luches, M. Martino, A. Zocco: Pulsed laser deposition of thin $\mathrm{SiO}_{2}$ and ITO films for optoelectronic applications, Vuoto XXIX, N. 3-4 (2000), 44-46

15. G. Barucca, G. Majni, P. Mengucci, G. Leggieri, M. Martino,: Monoclinic Carbon Nitride Phase Coherently Grown on Si(001) Substrates, Jou. Appl. Phys. 89(6) (2001) 3494-3497

16. S. Luby, E. Majkova, M. Jergel, G. Leo, S. Tundo, L. Vasanelli, E. D’Anna, A. Luches, M. Martino: The Thermal Stability of Tungsten/Silicon Multilayered Nanostructures, Materials Science and Engineering C 15 (2001) 187-189

17. C. Dutouquet, S. Acquaviva, J. Hermann, Detection of boron nitride radicals by emission spectroscopy in a laser-induced plasma, Spectrochimical Acta B: Atomic Spectroscopy 56B 6, (2001), 629-635

18. J. Hermann, F. Coursimault, O. Motret, S. Acquaviva, A. Perrone: Investigation of silicon oxide emission spectra observed in a pulsed discharge and a laser-induced plasma, J. Phys. B: At. Mol. Opt. Phys. 34 (2001), 1917-1927

19. M. De Sario, G. Leggieri, A. Luches, M. Martino, F. Prudenzano, A. Rizzo: Pulsed Laser Deposition Of Praseodymium-Doped Chalcogenide Thin Films, Appl. Surf. Scie. 186 (2002) 216-220. 
Military Technical College

Kobry Elkobbah,

Cairo, Egypt

May 29-31,2012

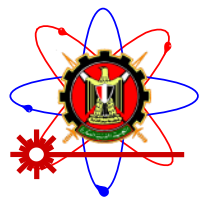

$6^{\text {th }}$ International Conference

on Mathematics and

Engineering Physics

(ICMEP-6)

20. P. Mengucci, G. Barucca, G. Majni, A. Di Cristoforo, G. Leggieri, M. Martino: Coherent carbon nitride phases grown on Si substrates by reactive laser ablation, Recent Res. Devel. Applied Phys. 5 (2002) 69-87

21. A. D’Orazio, M. De Sario, L. Mescia, V. Petruzzelli, F. Prudenzano, A. P. Caricato, G. Leggieri, M. Martino: Design and Fabrication of Praseodymium Doped Optical Waveguides, Proc. SPIE 4645 (2002) 174-182

22. A. P. Caricato, M. Fernandez, G. Leggieri, A. Luches, M. Martino F. Prudenzano: Pulsed laser Deposition of Films and Multilayers for Optoelectronic Applications Proc SPIE 4762 (2002) 41-51

23. S. Acquaviva and M.L. De Giorgi: Study of kinetics of atomic carbon during laser ablation of graphite in nitrogen atmosphere by time- and space- resolved emission spectroscopy, Appl. Surf. Sci. 186 (2002) 329-334

24. S. Acquaviva and M.L. De Giorgi: High-resolution investigations of $\mathrm{C}_{2}$ and $\mathrm{CN}$ optical emissions in laser-induced plasmas during graphite ablation, J. Phys. B: At. Mol. Opt. Phys. 35 (2002) 795-806

25. S. Acquaviva and M.L. De Giorgi: Temporal and spatial analysis of plasmas during graphite laser ablation, Appl. Surf. Sci. 197-198 (2002) 21-26

26. S. Acquaviva and M.L. De Giorgi: Fast ICCD photography of $\mathrm{XeCl}$ laser induced plasma of graphite in vacuum and in nitrogen atmosphere, J. Phys. B: At. Mol. Opt. Phys. 36 (2003) 247-260

27. S. Acquaviva and M.L. De Giorgi: Stoichiometric analyses of $\mathrm{Cd}_{1-\mathrm{x}} \mathrm{Mn}_{\mathrm{x}} \mathrm{Te}$ thin films deposited by pulsed laser ablation, Appl. Surf. Sci. (in press)

28. S. Acquaviva, A.P. Caricato, E. D’Anna, M. Fernández, A. Luches, Z. Frait, E. Majkova, S. Luby, P. Mengucci: Pulsed laser deposition of Co- and Fe-based amorphous magnetic films and multilayers, Thin Solid Films (submitted)

29. Metals handbook (ASM information), $2^{\text {nd }}$ edition, The Material Information Society, 2000.

30. "Deposition of ITO and AZO thin films by laser ablation at $355 \mathrm{~nm}$ in a background atmosphere", Ph.D. Thesis, Birgitte Thestrup, Riso National Laboratory, Roskilde, University of Copenhagen, Denmark, ISBN 97-550-2609-5, ISSN 0106-2840, Feb. 2000.

31. F. Fouquet, J.M. Pelletier, M. Pilloz and A.B. Vannes, in "Laser de puissance et traitements des matkriaux", edited by A.B. VANNES (Presses Polytechniques et Universitaires, Lausanne, Suisse, 1991) p. 217

32. . A.Y. FasasI, S.K. Roy, M. Pons, A. Galerie, D. Sibuet and M. Caillet, in MAT-TEC 92, edited by A. Niku-lari, (KIT International, Gournay/Marne, France, 1992) p. 211.

33. Metal handbook, Vol. 2,P S, Cambridge University press, 1980. 